\title{
Renewable Energy Startups and SME
}

Roshani Goel ${ }^{1}$

Institution name: Sanrachna Research Cell, SGT University

\begin{abstract}
India's energy needs are in demand with the increase in energy and other electric uses which is highest among the world. There are sectors which heavily rely on energy generated by fossil fuels but there is also seen a paradigm shift towards renewable energy sources. If India continues to rely on the former then they end up blocking development in energy system meeting uncertainties and face difficulties in supply of fossil fuels. To meet the fast-growing economy, India needs to supply the energy 3-4 times more of what they are supplying now. Government of India has become aware of the situation and has started facilitating polices in action towards a sustainable energy. As of 2019, India's on grid renewable energy capacity is 85.9 GW. Government is working to establish $500 \mathrm{GW}$ of renewable energy source by 2030 .
\end{abstract}

Keywords: renewable energy; startups; affordability; current condition; future potential

\section{Introduction}

Renewable energy sources have potential to provide solutions for long term energy supply problems especially in developing countries. Renewable energy is an important component for India energy planning. For sustainable energy base the importance of renewable energy source was recognised back in 1970's. Indian renewable energy sector is ranked fourth in renewable energy market in the world. India is ranked fourth in wind power, fifth in solar power and fifth in renewable power installed capacity as of 2018 (IBEF). It is expected that India to fulfil its energy demand on its own. According to Paris Agreement commitments, India is aiming to reach the renewable energy capacity of $175 \mathrm{GW}$ by 2022. This calculation is dispersed as 100 $\mathrm{GW}$ of solar energy and $60 \mathrm{GW}$ of wind energy. This calls for increase in market size attracting various companies as well as entrepreneurs. "As of February 2020, the installed renewable energy capacity is $86.75 \mathrm{GW}$, of which solar and wind comprises $34.40 \mathrm{GW}$ and $37.66 \mathrm{GW}$ respectively. Biomass and small hydro power constitute $9.80 \mathrm{GW}$ and $4.6 \mathrm{GW}$, respectively" (IBEF). With such development and with help of government policies it is estimated that northern India will soon become the hub of renewable energy source. Renewable energy is ecofriendly replacement of non- renewable source of energy taking towards the sustainable development. The great functioning of energy markets will give economic efficiency in main taking of coal, gas, oil and power sectors which are critical in assuring the energy security for future use.

Modern renewable energy is working to take over all forms of energy consumed sectors like transport, heating, cooling and power generation. Ministry of New and Renewable Energy (MNRE) is facilitating for implementation of programmes for harnessing renewable energy for rural areas for lightening, cooking, travelling, use of renewable energy in factories and in urban areas as a replacement of fuels also causing pollution. This has encouraged people to start and invest in renewable energy startups. India has both public and private and also joint ventures working to provide renewable energy for the above-mentioned sectors. This paper will look at

\footnotetext{
${ }^{1}$ Research Associate, Sanrachna, email: roshani_sanrachna@sgtuniversity.org
} 
policies for renewable energy startups and small and micro enterprises working on renewable energy sectors which can help them to become more stable and profitable.

\section{Renewable energy current condition: the trends}

India is one of the largest energy consuming country after United States, China and Russia. In order to look at current potential energies market it is important to grasp a hold over the growth in renewable energy sources, consumptions and transport and material used there. Currently, India has one of the largest programs. 'The Ministry of Nonconventional Energy Sources has been supporting R\&D for technology and manpower development in renewable energy'. Various efforts have been made for sustained development in this sector for consumer to draw sufficient amount of renewable energy. India, has abundance of renewable energy like solar, hydro, wind and biomass. However, these renewable energies are concentrated in fewer parts of India. Solar and wind energy is concentrated mainly in southern and western states of India that is, Tamil Nadu, Andhra Pradesh, Karnataka, Gujarat, Rajasthan and Maharashtra. The major source of renewable energy in India is solar energy with the potential of $68.33 \%$. These renewable energy helps in managing the power generated by coal and crude oil. As these reserves are limited for future generation. Coal deposits are mainly confined in eastern and central part of the country. States like Maharashtra, Odisha, Jharkhand, Chhattisgarh, Madhya Pradesh, Telangana and West Bengal account for $98.26 \%$ of total coal reserve in the country. Out of which Jharkhand has the maximum amount of coal reserve $26.06 \%$ in overall reserves in India. Ministry of Statistics and Programme Implementation (MoSPI) estimated coal reserves as 319.04 billion tonnes in March 2018, whereas the total reserve of Lignite is 45.66 billion tonnes. Crude oil reserves are 594.49 million tonnes which is concentrated mainly in western offshores. Natural gas reserves are 1339.57 billion cubic meters in 2018 .

According to MoSPI data "Compound Annual Growth Rate (CAGR) of Production of Coal \& Lignite in $2017-18$ over $2008-09$ are $3.20 \%$ \& 3.62\% respectively whereas their consumption grew at $5.01 \%$ and $3.70 \%$ respectively during the same period. In case of Crude Oil and Natural Gas, during the period 2008-09 to 2017- 18 the Production increased by $0.63 \%$ and (-) $0.06 \%$ whereas Consumption increased by $4.59 \%$ \& $4.82 \%$ ". India relies heavily on coal production of electricity supply. In order to provide supply to rural areas it is highly recommended to make a shift from replenishable energies to renewable form of energy sources.

In India, solar power is in abundance. The solar power where sun hits the atmosphere is $1017 \mathrm{~W}$ and world demand for power energy is $1013 \mathrm{~W}$. In others words, by using only $5 \%$ of this energy will be equal to 50 times of power of what world requires. "The National Solar Mission targeting 20,000 MW grid solar Power, 2,000 MW of off-grid capacity including 20 million solar lighting systems and 20 million square meters solar thermal collector area by 2022 is under implementation" (Narnaware, Surose and Gaikwad, 2015, p.35). In addition, wind power makes upto 68 percent of renewable power capacity installed in India. The sector which is not readily developed is hydro power capacity. India has a potential for small hydro power that is, under $25 \mathrm{MW}$ in capacity. Nevertheless, the sector is growing rapidly ever since. Another is Biomass energy which has a huge potential in an agrarian economy like India. The energy is derived from numerous sources as well as by-products like factory waste and animal dung. Together these renewable sources of energy not only help in climate protection but also economically favourable. 
Table 1: Shows the Physical Progress of renewable energy

Programme/Scheme wise Physical Progress in 2020-21 \& Cumulative upto June, 2020

\begin{tabular}{|l|l|l|l|}
\hline \multirow{2}{*}{ Sector } & \multicolumn{2}{|l|}{ FY- 2020-21 } & $\begin{array}{l}\text { Cumulative } \\
\text { Achievements }\end{array}$ \\
\cline { 2 - 4 } & Target & $\begin{array}{l}\text { Achievements } \\
\text { (April- } \\
\text { June 2020) }\end{array}$ & $\begin{array}{l}\text { (as } \\
\text { (30.6.2020) }\end{array}$ \\
\hline
\end{tabular}

I. GRID-INTERACTIVE POWER (CAPACITIES IN MWp)

\begin{tabular}{|c|c|c|c|}
\hline Wind Power & 3000.00 & 85.80 & 37829.55 \\
\hline Solar Power - Ground Mounted & 9000.00 & 192.66 & 32305.15 \\
\hline Solar Power - Roof Top & 2000.00 & 301.85 & 2817.15 \\
\hline Small Hydro Power & 100.00 & 5.00 & 4688.16 \\
\hline Biomass (Bagasse) Cogeneration) & 200.00 & 0.00 & 9200.50 \\
\hline $\begin{array}{l}\text { Biomass (non-bagasse) Cogeneration)/Captive } \\
\text { Power }\end{array}$ & 50.00 & 5.00 & 679.81 \\
\hline Waste to Power & 30.00 & 1.20 & 148.84 \\
\hline Total & 14380.00 & 591.51 & 87669.16 \\
\hline \multicolumn{4}{|c|}{ II. OFF-GRID/ CAPTIVE POWER (CAPACITIES IN MWEQ) } \\
\hline Waste to Energy & 10.00 & 2.41 & 200.51 \\
\hline SPV Systems & 500.00 & 2.45 & 980.84 \\
\hline Total & 510.00 & 4.86 & 1181.45 \\
\hline \multicolumn{4}{|c|}{ III. OTHER RENEWABLE TECHNOLOGIES (Capacity in Nos.) } \\
\hline Biogas Plants (in Lakhs) & 0.60 & 0.27 & 50.50 \\
\hline
\end{tabular}

Source: Ministry of New and Renewable Energy,2020 


\section{Geographical distribution of renewable energy in India}

Table 2: State-wise installed capacity of Grid Interactive Renewable Power as on 31.12.2018.

\begin{tabular}{|c|c|c|c|c|c|c|}
\hline S.NO. & $\begin{array}{l}\text { STATES/ } \\
\text { UTS }\end{array}$ & $\begin{array}{l}\text { Small } \\
\text { Hydro } \\
\text { Power }\end{array}$ & $\begin{array}{l}\text { Wind } \\
\text { Power }\end{array}$ & $\begin{array}{l}\text { Bio } \\
\text { Power }\end{array}$ & $\begin{array}{l}\text { Solar } \\
\text { Power }\end{array}$ & $\begin{array}{l}\text { Total } \\
\text { Capacity }\end{array}$ \\
\hline & & (MW) & (MW) & (MW) & (MW) & (MW) \\
\hline 1 & $\begin{array}{l}\text { Andhra } \\
\text { Pradesh }\end{array}$ & 162.11 & 4076.45 & 500.34 & 2641.76 & 7380.66 \\
\hline 2 & $\begin{array}{l}\text { Arunachal } \\
\text { Pradesh }\end{array}$ & 107.100 & & & 5.39 & 112.49 \\
\hline 3 & Assam & 34.11 & & & 16.68 & 50.79 \\
\hline 4 & Bihar & 70.70 & & 121.20 & 142.45 & 334.35 \\
\hline 5 & Chhattisgarh & 76.00 & & 230.50 & 231.35 & 537.85 \\
\hline 6 & Goa & 0.05 & & & 1.69 & 1.74 \\
\hline 7 & Gujarat & 35.10 & 5955.07 & 77.30 & 1827.38 & 7894.85 \\
\hline 8 & Haryana & 73.50 & & 205.66 & 217.09 & 496.25 \\
\hline 9 & $\begin{array}{l}\text { Himachal } \\
\text { Pradesh }\end{array}$ & 860.61 & & 7.20 & 3.89 & 871.70 \\
\hline 10 & \begin{tabular}{|l} 
Jammu \& \\
Kashmir
\end{tabular} & 179.03 & & & 9.85 & 188.88 \\
\hline 11 & Jharkhand & 4.05 & & 4.30 & 32.41 & 40.76 \\
\hline 12 & Karnataka & 1230.73 & 4682.80 & 1799.80 & 5255.11 & 12968.44 \\
\hline 13 & Kerala & 222.02 & 52.50 & 0.72 & 138.49 & 413.73 \\
\hline 14 & $\begin{array}{l}\text { Madhya } \\
\text { Pradesh }\end{array}$ & 95.91 & 2519.890 & 120.75 & 1586.25 & 4322.80 \\
\hline 15 & Maharashtra & 375.570 & 4788.13 & 2528.69 & 1607.79 & 9300.81 \\
\hline 16 & Manipur & 5.45 & & & 2.59 & 8.04 \\
\hline 17 & Meghalaya & 31.03 & & 13.80 & 0.08 & 44.91 \\
\hline 18 & Mizoram & 36.47 & & & 0.20 & 36.67 \\
\hline 19 & Nagaland & 30.67 & & & 1.00 & 31.67 \\
\hline 20 & Odisha & 64.625 & & 59.22 & 389.40 & 513.25 \\
\hline 21 & Punjab & 173.55 & & 326.35 & 905.62 & 1405.52 \\
\hline 22 & Rajasthan & 23.85 & 4299.72 & 121.30 & 3130.99 & 7575.86 \\
\hline 23 & Sikkim & 52.11 & & & 0.01 & 52.12 \\
\hline 24 & Tamil Nadu & 123.05 & 8631.19 & 1003.88 & 2228.44 & 11986.56 \\
\hline 25 & Telangana & 90.87 & 128.10 & 177.60 & 3410.26 & 3806.83 \\
\hline 26 & Tripura & 16.01 & & & 5.09 & 21.10 \\
\hline 27 & Uttar Pradesh & 25.10 & & 2117.51 & 891.01 & 3033.62 \\
\hline 28 & Uttarakhand & 214.320 & & 130.50 & 303.81 & 648.00 \\
\hline 29 & West Bengal & 98.50 & & 319.92 & 42.32 & 460.74 \\
\hline 30 & $\begin{array}{l}\text { Andaman \& } \\
\text { Nicobar }\end{array}$ & 5.25 & & & 6.56 & 11.81 \\
\hline
\end{tabular}




\begin{tabular}{|l|l|l|l|l|l|l|}
\hline 31 & Chandigarh & & & & 32.40 & 32.40 \\
\hline 32 & $\begin{array}{l}\text { Dadar \& } \\
\text { Nagar Haveli }\end{array}$ & & & & 5.46 & 5.46 \\
\hline 33 & $\begin{array}{l}\text { Daman \& } \\
\text { Diu }\end{array}$ & & & & 13.38 & 13.38 \\
\hline 34 & Delhi & & & 52.00 & 124.21 & 176.21 \\
\hline 35 & Lakshadweep & & & 0.75 & 0.75 \\
\hline 36 & Pondicherry & & & & 1.73 & 1.73 \\
\hline 37 & Others & & 4.30 & & & 4.30 \\
\hline & Total (mw) & $\mathbf{4 5 1 7 . 4 4 5}$ & $\mathbf{3 5 1 3 8 . 1 5 0}$ & $\mathbf{9 9 1 8 . 5 4}$ & $\mathbf{2 5 2 1 2 . 2 6}$ & $\mathbf{7 4 7 8 6 . 4 0}$ \\
\hline
\end{tabular}

Source: Press Information Bureau, Ministry of New and Renewable Energy

\section{Future Scope}

India has a positive scope in renewable energy sources with the rising demand for energy consumption. As mentioned earlier India is a sun favoured country thus, a scope for abundant solar energy. India receive 5000TWh of solar segregation if only 10 percent of this energy is used then this will help in solving majority of energy problems. If India meets its expected installed energy capacity then will be producing 71 percent of total energy produced. This can only be achieved by installing solar plants in the areas which receives highest sun rays. This can be simplified by referring table 2 . In this sector private players seems to play a vital role for expansion of this sector as $35 \%$ of country's power is generated by this sector. In near future government is expected to announce privatisation of most of the discoms to improve their performances (Tim, 2020, p.2).

India's electricity production has expanded and increased rapidly through investment in thermal and renewable energy sector. The country has shifted its focus to higher share of renewable energy which requires establishment and flexibility priority. Government of India has started using its interconnection across the country. They are also promoting affordable battery storages. To initiate flexibility in term of financing, market and production government of India working on placing the electricity market reform to create an appropriate pricing mechanism and continuous regulatory framework.

India has been successful in achieving United Nations sustainable Development goals by providing energy access. However, there is still a commendable rise in carbon di oxide emission. India's per capita emission of carbon di oxide in 2020 is 1.6 tonnes which is $6.4 \%$ of total global share of emission. The country is the active supporter for favourable climatic conditions. The country Nationally Determined Contribution under the Paris Agreement sets a target for reducing the carbon emissions and more use of non- fossil fuels for power generation. The paper portrays a picture of how government has been working to achieve such target and to some extent it has been able to do so (IEA, 2020).

Based on current estimation, India's power demand will be doubled by 2040, with electricity demand in appliances ownerships and cooling needs. Thus, the country needs massive amount of power generation capacity to fulfil the supply of air conditioning units. India's current generating capacity is $366 \mathrm{GW}$ and is aiming to add $175 \mathrm{GW}$ by 2022 . This target has offered a scope for new players to take part in making the target achievable. Thus, there is a huge scope and demand in renewable energy sectors. 


\section{Renewable energy Startups in all over India}

Technology is aim to reduce human effort or provide hand to them. But soon there were consequences like increase in pollution level and global warming hampering the environment. As people are getting aware of energy consumption and its sources, they are getting more inclined towards renewable energy sources. This is one of the main reasons for people to invest and start business of establishing and providing renewable energy. These startups are known as Green Start-ups or CleanTech. One of the most clean and renewable energy in India is solar energy. With the help of Indian government people have seemed opportunity in solar energy sector.

Companies like ReNew Power, Cygni Energy, CleanMax Solar are some of the startups who have managed to raise good amount of money in few years. ReNew Power was founded in 2015 by Sumant Sinha, The son of former Finance Minister. The startup provide renewable energy solution to increase the adoption of clean energy. The company have said to have 200 distribution of solar installation sites in 16 states and two Union territories. In 2019 the company managed to raise 2,050 crore rupees through rights issue from Goldman Sachs and Canada Pension Plan Investment Board (The Indian Wire, 2019). CleanMax Solar is a Mumbai based startup founded in 2011. It is also providing solution to its clients like rooftop solar to reduce energy cost. The startup has managed to raise 275 crore rupees from UK Climate Investment in 2019. Cygni Energy is a Hyderabad based solar energy startup founded in 2015. It provides novel solar DC solutions and DC power at affordable price to have a clear and green energy. They have powered 20,000 homes across 10 states in India. The company has manged to raise money through equity and debt funding by firm named Endiya Partners with IndusInd Bank.

Other than this there are Azure Power, Fourth Partner Energy, MYSUN, Solar91 and ONergy Solar, ZunRoof and MinionLabs startups who provide rooftop solar solutions to their clients like solar rooftop kits, Solar water pumps, solar mobile charger, solar lighting and microgrids.

Other rising startups are Bengaluru based Orb Energy which provide off-grid and grid-tied solar solutions established in 2006. They help small and medium enterprises including low income individuals to reduce their electricity bill by providing affordable solar solution. They also provide collateral free solar loans. Another is Claro Energy founded in 2011. They provided solar water pumping solutions to deal with agricultural needs of a farmer like irrigation and drinking in order to increase productivity. Oorjan is next in the list founded by IIT alumni's in 2014. They provide solar solution and also help their low-income customers to cater easy loans through their partnership with different banks. Nuevosol Energy established in 2011 providing ground mounted solar panels. They have helped 22 states in India. The company take contracts from infrastructure companies taking projects more than three months. 8Minutes was founded in 2015 by providing affordable solar energy solutions making it more accessible for people. The company has already managed to have $26 \mathrm{MW}$ of solar assets in deployment producing 39 million $\mathrm{kWh}$ of power annually and 29,000 metric tons of CO2 emission is offset (Mishra, 2018). Sun Mobility was founded by Chetan Maini inventor of Reva now known as Mahindra Reva is working vehicles by replacing them with electric consuming vehicles. They are producing batteries in which more energy is stored. They are planning to store energy in batteries through solar panels and distribute it through regular 
pattern that is, petrol pumps. Intend to integrate all forms of vehicles like rickshaws, buses, scooters and cars.

Mera Gao Power also known as 'My Village' a microgrid startup primarily established in Uttar Pradesh. They have managed to serve 1,50,000 individuals and 1600 villages across the state. The company provides reliable lighting and mobile charging solutions. It is the first commercially viable microgrid for rural population (Mishra, 2018). they provide service for $\$$ 1,000 making it lowest cost design. U.S Agency for International Development was their first investor. They have also selected as Technology Pioneer by World Economic Forum. Similar to it is Gram Power founded in 2010. The company provide smart grid technology to cater with electrification challenges. 'In March 2012, the startup set up India's first Solar Powered Smart Microgrid in the Rajasthan hamlet of Khareda Lakshmipura, providing energy for lights, buttermilk machines, televisions and fans' (IndianWeb, 2016). They have provided smart grids to 30 rural areas. Barrix Agro Sciences is a company which provide eco- friendly pest control measures which are currently being employed in agriculture. They are focusing on extensive research before making it applicable to all over India. The company is expected to be successful for unique next generation pest management tools and produce. These products are ecofriendly and help to produce non- chemical-based crops. Avant Garde Innovation is a Trivandrum, Kerala based cleantech startup which is committed to produce $100 \%$ of renewable energy. The company is making wind turbines which are affordable and sustainable and are high at performance for residential, commercial agricultural and rural electrification uses (IndianWeb, 2016). Husk Power System is situated in Bihar. The company uses biomass gasifier to generate electricity. Their aim is to provide electricity to the rural population. Through the use of their proper tiered technology they have served 400 household in rural area, saving 18,000 litres of diesel and 42,000 of petrol every year. Green India Building Systems and Services (GIBSS) is a Hyderabad based startup founded in 2010 offering geothermal cooling technology, LED indoor lighting and hot water cooler. The company has an office in Singapore as well. Tessol Thermal Energy Solutions is a Mumbai based company who aim to transform the way thermal energy being produced and consumed in today's time. The startup has developed technology that impact thermal applications in agricultural and industrial sectors. "Tessol is currently focusing on the cold chain sector - transportation as well as stationary storages using the cold plates technology. It uses the brand name 'PlugnChill' for this solution" (IndianWeb, 2016). PlundnChill operated without the use of diesel for refrigeration ensuring temperature stability with reducing the cost by $60 \%$.

IndiaGoSolar is a Delhi based company founded in 2014. It provides advisory and information regarding solar products, its technology, market supplies, price comparison, benefits, delivery and installation. The aim of the company is to make consumers adaptable to green energy.

\section{Startups generating sectors}

India's power capacity has surged from $13 \%$ to $20 \%$ in 2018 and is expected to grow in coming years. This is beneficial for country's climate goals and economically favourable as renewable energy is cheaper than thermal power which is one of the main reasons for a transmission to a renewable energy generator than the existing form of power consumption. Solar and wind energy sources are erratic as they are completely depended on weather therefore, power 
generating companies manage it by balancing it between renewable energy and thermal power to provide an uninterrupted flow of energy.

In such sector demand forecast and procurement forecast is crucial from financial and technological point of view. If the company under procure electricity then they fail to meet demand and if they over procure then they lose the money. Thus, there are companies who forecast and provide services to power producers like REConnect Energy. This company helps in forecasting wind power generation and work with different states to help them manage their power flows. In order words, renewable energy startups has also produced direct, indirect and induced employment (Terii, 2015). There are utilities who are working on pilot projects in collaboration with startups in states like Uttar Pradesh, Gujarat, Karnataka and West Bengal.

Companies like Quenext a Mumbai based utility aggregate data on power plants and provide it for public use. Climate Connect on the other hand tells about which power from a power plant should buy based on financial and demand requirement. These companies especially Quenext use satellites to identify solar panels and overlay weather data on it. They help in mapping out each solar and wind power plants. Thus, such primary startups work internationally as well as nationally in collaboration with government and private players (Sushma, 2018).

\section{The bigger picture}

As per parliamentary standing committee report India has an ambition of National Solar Mission Plan to achieve $40 \mathrm{GW}$ of rooftop solar power generating capacity by 2022 . 'As of October 15, 2019, India has only achieved 1,826 MW of rooftop solar capacity, which should have been 16,000 MW. However, progress in the sector has been slow' (Yourstory, 2019). The committee mentioned that Ministry of New and Renewable Energy has failed to achieve yearly targets of clean energy of having more of $175 \mathrm{GW}$ power added to existing capacity by 2022 . A startup named Distributed Energy has claimed to find a solution to it and is willing to help India to achieve its target.

Distributed Energy is an aggregator which forms a link between the renewable projects and investors on a digital platform. The startup conducts a comprehensive research before enlisting the funding project on the market and investors can explore as well as express interest related to projects. The startup has already managed to deliver $5 \mathrm{MW}$ of energy to various companies in southern India. The startup incorporated in 2019 with team in Chennai, Kochi and Dubai and deliver execution, operations and maintenance of solar rooftops panels with main focus in India and Africa. "The founders claim that Distributed Energy solves two primary problems, first, it standardises the fragmented deployment of solar rooftop projects in the commercial and industrial sector, and second, it offers opportunities to investors to invest in the renewable energy" (Yourstory, 2019).

In aggregating the deal, the startup gets a small percentage in the equity in plant ownership and a small percentage of revenue from the plant. From June 2019 the startup already has 5 MW projects in deployment worth $\$ 3.5$ million and pipeline projects over $\$ 15$ million worth.

\section{Conclusion}

With the shift in focus towards renewable energy government is making effort in strengthening the innovation and technology in power grids, cooling, advanced biofuels and energy consumption technologies. With the vision of such promotion government is encouraging new 
members to establish renewable energy sources like solar charging infrastructure, production of lithium batteries and solar PV. In recent years there has been a remarkable increase in the renewable $\mathrm{R} \& \mathrm{D}$ funding and is expected to double its investment in coming years to meet the future increasing demands. The framework of ministries is constantly coordinating for public with private funding. Energy security and environment protection is a national policy driver for economic growth and development. The critical solution to it is promotion of renewable energy startups. The upcoming startups for the manufacturing of small hydro power and electricity generators and also the promotion of counselling to use of renewable energy in industrial and urban sectors ha streamed the national power generating capacity. The startups are not only at knowledge process but also as a mediator and a service provider to both public and private use with funding solution through bank linkups. In order words renewable energy sources has enormous benefits and contribute significantly in energy mix consumption at lower cost for the entire nation.

\section{References}

Buckley, Tim. 2020, India's Renewable Energy Policy Headwinds Recommendations for Urgently Accelerating Activity in the Renewable Energy Sector, Institute for Energy Economics and Financial Analysis, pp.1-32. Accessed from: https://ieefa.org/wpcontent/uploads/2020/02/Indias-Renewable-Energy-Policy-Headwinds_February-2020.pdf

GOVERNMENT OF INDIA, Ministry of New and Renewable Energy, 2019. Press Information Bureau. Accessed from:

https://pib.gov.in/Pressreleaseshare.aspx?PRID=1564039 
GOVERNMENT OF INDIA, Ministry of New and Renewable Energy. 2020, Programme/Scheme wise Physical Progress in 2020-21 \& Cumulative upto June, 2020. Accessed From: https://mnre.gov.in/the-ministry/physical-progress

GOVERNMENT OF INDIA, Ministry of Statistics and Programme Implementation. 2019, Energy Statistics. Accessed from: http://www.mospi.gov.in/sites/default/files/publication_reports/Energy\%20Statistics\%20201 9-finall.pdf

IEA. 2020, Energy Policy Review. Accessed form: https://www.iea.org/reports/india-2020

Indian Brand Equity Foundation, Renewable Energy Industry in India. March 2020, Accessed from: https://www.ibef.org/industry/renewable-energy.aspx

IndianWeb, 16/94/2016. 10 Promising Cleantech Startups In India Right Now, Accessed from: https://www.indianweb2.com/2016/04/13/7-promising-cleantech-startups-india-right-now/

Mishra, Tamanna. 2018, Harnessing the sun: startups who are lighting the way ahead for India's renewable energy sector, Accessed from: https://yourstory.com/2018/01/solar-energystartups-india-renewable-energy

Narnaware, Preeti H; Surose, Ramesh G and Gaikwad, Swati V. 2015, Current Status and The Future Potentials of Renewable Energy in India- A Review, International Journal of Advances in Science Engineering and Technology, 1, pp.32-38. Accessed from: http://www.iraj.in/journal/journal_file/journal_pdf/6-151-143471472733-38.pdf

The Energy and Resource Institute, Renewable Energy and Green Growth in India. 2015, Accessed from: https://www.teriin.org/projects/green/pdf/National-RE.pdf

The Indian Wire, 28/05/2019. List of top 15 solar energy startups, helping India transition to sustainable energy sources, Accessed from: https://www.theindianwire.com/startups/top-solarstartups-india-75748/

U, Sushma N. 2018, Tech Startups are Helping India's Creaky Power Sector Cope with the Renewable Energy Boom. Accessed from: https://qz.com/india/1326552/indias-renewableenergy-boom-has-put-tech-startups-in-charge-of-the-power-sectors-transition/

Yourstory, 2019. How This Startup is Helping India Meet National Solar Mission Goal by Matching Projects and Investors. Accessed from: https://yourstory.com/2019/12/indiastartup-national-solar-mission-distributed-energy?utm pageloadtype $=$ scroll 